\title{
Body as a New Social Medium in Lithuanian Performative Arts: How Discourse Comes to Matter
}

\author{
Basia Nikiforova, Kestutis Sapoka
}

This article deals with the concept of new materialism and examines the issue of how new materialism tackles visual art in innovative ways - though the intersections of artistic practice, art-as-research, and philosophical analysis. Selected artworks by S \& P Stanikas and Evaldas Jansas are analyzed in this paper as body reconceptualization in Lithuanian art, employing the approach of new materialism. We will explore the geopolitical and ideological background, in which Lithuanian and Polish visual artists grapple with cultural binaries from the 1960s to the 1990s: male-female gendered bodies, traditional or contemporary art, and the artist as free individual or the one tied to ideology. Employing Rossi Braidotti's term "affirmative", this article poses a question whether it is possible to argue on the analyzed cases that "affirmative politics combines critique with creativity in the pursuit of alternative visions and projects".

Key words: abjection, commodities, body reconceptualization, emotional terror, matter, new materialism, post-humanism, sexuality, violence

The meaning of the body is one of the most debatable matters in contemporary philosophy. In our view, the broader definition of the concept implies that

BASIA NIKIFOROVA, Lithuanian Culture Research Institute, Lithuania; address for correspondence: Lithuanian Culture Research Institute, Vilnius, Saltoniškių g. 58, LT-08105; e-mail: bnikiforova@hotmail.com

KESTUTIS SAPOKA, Lithuanian Culture Research Institute, address for correspondence: Lithuanian Culture Research Institute, Vilnius, Saltoniškių g. 58, LT-08105; e-mail: kestas.sapoka@gmail.com 
the bodily/aesthetic basis is important to general philosophy and the expansive understanding of meaning as such. In the book "The Meaning of the Body. Aesthetics of Human Understanding" Mark Johnson states that "meaning is not just a matter of concepts and propositions, but also reaches down into the images, sensorimotor schemas, feelings, qualities, and emotions that constitute our meaningful encounter with our world. Any adequate account of meaning must be built around the aesthetic dimensions that give our experience its distinctive character and significance"2. To him, any comprehensive account of the meaning of the body should necessarily include analyses of the five key dimensions: biological, ecological, phenomenological, social, and cultural ${ }^{3}$.

In the 1960-70s the body itself became a focus of systematic theoretical philosophical and cultural studies. Mary Douglas introduced the notion of the body as a system of "natural symbols" that metaphorically reproduce social categories as an "image of society"4. From her point of view, the experience of an individual body is "always modified by the social categories through which it is known". "The body is perhaps the primary metaphor for a society's perception of itself. The individual and spoken language are what make up the social body. The physical body is a kind of boundary between biology and society, between drives and discourse. Man can only know himself through his environment. Our awareness of self-heightens our awareness of the world around us" ${ }^{\text {. }}$

In her article "Foucault, Femininity, and the Modernization of Patriarchal Power" (late 1970s) the feminist Sandra Lee Bartky writes on the socially accepted "norms" for a woman's body and behavior and makes the point that women are often judged for their size and shape because their bodies reflect their personality and nature. She refers to the fact that the "ideal body of femininity is constructed" and states that this perfect woman reflects the cultural obsessions, expectations and society's preoccupations. Continuing the ideas of Douglas, Bartky explains

${ }^{2}$ M. Johnson, The Meaning of the Body. Aesthetics of Human Understanding, University of Chicago Press, Chicago 2007, p. XI-XII.

${ }^{3}$ Ibidem, p. 275-278.

${ }^{4}$ M. Douglas, Purity and Danger: An Analysis of the Concepts of Pollution and Taboo, Routledge and Kegan Paul, London 1966, p. 98.

${ }^{5}$ Ibidem, p. 72.

${ }^{6}$ A. Jones, Body Art: Performing the Subject, University of Minnesota Press, Minneapolis 1998, p. 99. 
that the body of the ideal female changes with time and stages of culture. According to her, in contemporary society, the ideal body is one that is "taut, smallbreasted, narrow-hipped, and of a slimness bordering on emaciation" or that of a newly pubescent girl. Using the social metaphor, this look of fragility and lack of muscular strength allows women to create an image of powerlessness, obedience, and subservience to men. "The disciplinary project of femininity is a »setup «: it requires such radical and extensive measures of bodily transformation that virtually every woman who gives herself to it is destined in some degree to fail"'?

\section{Body' Phenomenological Perception}

The classical subject-object dichotomy step by step is dissolved and was found an area "between" subject and object. Maurice Merleau-Ponty was not the first phenomenologist to draw attention to the body but he placed the ambiguity of the body, as materiality and consciousness at the center of his philosophical research. He radically rejects Cartesian dualism, which places the human body in the same ontological category as the 'objects' of the physical sciences, and identifies the subjectivity of the human with its consciousness, with its being which inevitably related to its body. "The union of soul and body is not an amalgamation between two mutually external terms, subject and object, brought about by arbitrary degree. It is enacted at every instant in the movement of existence". For Merleau-Ponty the human body is itself a 'subject', and the human subject is necessarily, not just contingently, embodied. "Phenomenology of Perception" Part 1 was devoted to the articulation and justification of the body-subject conception. Consequently, humans came to be seen as composed of two distinct substances, consciousness and matter, mind and body. Using Husserl's conception of the lived world, he starts by exploring one specific aspect of this, the lived body. It was his attempts to provide a phenomenological account of the human body,

${ }^{7}$ S. L. Bartky, Foucault, femininity and the modernization of patriarchal power, [in:] Feminism and Foucault: Reflections on Resistance, ed. by I. Diamond \& L. Quinby, Northeastern University Press, Boston 1988, p. 33-34.

${ }^{8}$ M. Merleau-Ponty, Phenomenology of Perception, transl. by C. Smith, Routledge, London 1962, p. $88-89$. 
focusing primarily on our bodily existence. The body subjectivity is not a consciousness 'inhabiting' such an object. Further, the world as it is for the human subject is 'for' an embodied subject, not for a disembodied consciousness.

Human "being-in-the-world" is a bodily being and it is requiring its adequate description with philosophical categories. For Merleau-Ponty, the human body is not only challenging the possibility conceptualize it as a scientific object or humans as composed of such a body and an ontologically distinct consciousness. He proposes that humans in some sense are "bodies" but the body Merleau-Ponty investigates and describes is not the objective body, in its materiality, but the subjective, lived body, in its constant "dialogue" with the world. He presents an idea about the special status of the human body:

"Now the permanence of my own body is entirely different in kind: it is not at the extremity of some indefinite exploration; it defies exploration and is always presented to me from the same angel. Its permanence is not permanence in the world, but permanence on my part. To say that it is always near me, always there for me, is to say that it is never really in front of me, I cannot array it before my eyes, that it remains marginal to all my perceptions, that it is with me. It is true that external objects too never turn one of their sides to me without hiding the rest, but I can at least freely choose the side which they are to present to me"

Jennifer Bullington adds that the materiality of the body is obligatory in that it set the frame for our possibilities, but we are not only determined by our physical being. "Our concrete existence as beings who live in a meaningful world is never the product or result of physiological processes. We are also psychological, cultural beings"10.

\section{New Materialism Approach as Theory of Body Deconstruction}

Nowadays, visual art is not concerned about the beauty of the body. The concept of new materialism examines the issue of how new materialism tackles visual art in innovative ways - through the intersections of artistic practice, art-as-research, and philosophical analysis. Selected artworks by S. and P. Stanikas and

\footnotetext{
${ }^{9}$ Ibidem, p. $90-91$.

${ }^{10} \mathrm{~J}$. Bullington, The Expression of the Psychosomatic Body from a Phenomenological Perspective, Springer, New York-London 2013, p. 28.
} 
Evaldas Jansas are analyzed as body reconceptualization in Lithuanian art, employing the approach of new materialism. Our attempt to understand body reconceptualization and deconstruction through the categories of new materialism is an important aim of our research. Barad's concept of intra-action (which implies a clear-cut subject-object distinction) is crucial because of the existing possibility to explain the statement that "bodies are not objects with inherent boundaries and properties" and the analyzed representations are "material-discursive phenomena". Employing Rossi Braidotti's term "affirmative", we pose a question whether it is possible to argue on the analyzed Lithuanian cases, since "affirmative politics combines critique with creativity in the pursuit of alternative visions and projects". At the moment, art and art philosophy critics experience "the need for a systematic meta-discursive approach" which would explain innovative art tendencies on the interdisciplinary level. Braidotti points out that "it stresses instead the need for an ethics based on the necessity of meeting the challenges of the contemporary transformations with creativity and courage"11.

"Post-human body" is an important concept which serves as the key to explanation of the innovative visual art tendency. In the view of Judith Halberstarn and Ira Livingston, "post-human bodies are the causes and effects of postmodern relations of power and pleasure, virtuality and reality, sex and its consequences"12. They have found specific characteristics or meanings which help not only to understand this definition but also to apply it to our visual arts cases.

"Post-human body" is:

- Post-human bodies are the causes and effects of postmodern relations of power and pleasure, virtuality and reality, sex and its consequences.

- "Constructionist body" which is not equal to the task if it is merely a compensatory or reactionary opponent to the humanist body.

- Post-human bodies emerge at nodes where bodies, bodies of discourse, and discourses of bodies intersect to foreclose any easy distinction between actor and stage, between sender/receiver, channel, code, message, context.

${ }^{11}$ R. Braidotti, A Critical Cartography of Feminist Post-postmodernism, "Australian Feminist Studies" 2005, vol. 20, no. 47 (July), p. 178.

${ }^{12}$ J. M. Halberstam and I. Livingston, Posthuman Bodies, Indiana University Press, Bloomington 1995, p. 3. 
- The human body itself is no longer a part of "the family of man" but of a zoo of post-humanities.

- Post-human bodies thrive in subcultures without culture: there are only subcultures. Culture processes and appropriates a subculture only as quickly as the subculture becomes visible as culture.

- The search for origins of the post-human is difficult because we are the origins at which imagined reality, virtual reality and gothic reality are available.

- The post-human marks a solidarity between disenchanted liberal subjects and those who were always already-disenchanted, those who seek to betray identities that legitimize or de-legitimize them at too high a cost.

- The posthuman becoming-subject vibrates across and among an assemblage of semi-autonomous collectivities it knows it can never either be coextensive with nor altogether separate from ${ }^{13}$.

\section{“Entangled" Autonomy: Art between Commodity and Value}

Art as a commodity embodies different concepts by transforming them into material goods, capable of being marketable and collected. By interacting with the global economy, art subjects perpetuate themselves. "As a concept, then "art" is not an economy free zone. Consequently, the notion of art and economy as a pair of polar opposites is untenable"14.

Artistic autonomy is linked with market in a very specific way:

- the context of art as a commodity must first be understood within its own changeable environment

- it has a unique position of a sub-market within the global economy

- the art market is comprised of commodities embodied by culturally specialized qualities

- it is often problematic in the sense that it resists being measurable

- however, it cannot claim to be completely separate from the broader economy in terms of systems of production, promotion and criticism.

\footnotetext{
${ }^{13}$ Ibidem, p. 3-14.

${ }^{14}$ I. Graw, High Price: Art Between the Market and Celebrity Culture, Sternberg Press, Berlin 2009, p. 66.
} 
- the financial crisis revealed just how much fortune of the art world is tied to financial markets

- investment in art as a stable commodity has often periods of recession

- art criticism and promotion has converted much of the ambiguity value of artworks into valuable assets by turning symbolic capital into financial.

Arjun Appadurai, Nicholas Thomas, Igor Kopytoff and other cultural anthropologists have begun to take into account the way objects flow between these spheres of exchange. They refocused their attention on "the social life of things". They examined the strategies by which an object could be "singularized": start to be unique and special, and so, withdrawn from the market. Nicholas Thomas examines the same range of cultures and the anthropologists who write on them, and redirects his attention to the "entangled objects" and their roles as both gifts and commodities ${ }^{15}$. Appadurai suggests that "commodities, like persons, have social lives", and to appropriately understand the human-ascribed value of a commodity, one must analyze "things-in-motion" - the entire lifecycle of an object, including its form, use, and trajectory as a commodity. The reason for this kind of analysis linked with Appadurai's suggestion that a commodity is not a thing, but rather a phase in the full life of a thing. According to him, "the flow of commodities in any given situation is a shifting compromise between socially regulated paths and competitively inspired diversions"16.

\section{Lithuanian Visual Art in Search of Body Reconceptualization. Evaldas Jansas: Own Artist Body as Object and Abject}

The reconceptualization of aesthetics has challenged the new generation of Lithuanian visual artists whose creativity is closely linked with body as subject of art and with art performance encompassing the body. Evaldas Jansas, a member of the generation of Lithuanian performers and video artists who started their activity in the last decade of the twentieth century, is noted for his performances

${ }^{15}$ N. Thomas, Entangled Objects: Exchange, Material Culture, and Colonialism in the Pacific, Harvard University Press, Cambridge 1991.

${ }^{16}$ A. Appadurai, Introduction: Commodities and the Politics of Value, [in:] The Social Life of Things: Commodities in Cultural Perspective, ed. by A. Appadurai, Cambridge University Press Cambridge 1986, p. 17. 
characterized by hyper-corporality ${ }^{17}$. Jansas can as well be called an artist-anthropologist. The artist's own body becomes "objects and abject of art" in the real and detailed senses. It can be traumatized, self-violated, deconstructed and become matter in different ways. He often demonstrates a different dimension of scatological movement, body fluids and juice. In his early performances Jansas demonstrated possibilities to change physical functions of a single body through disassembling, deromanticizing, demetaphorization, and desocialization. He wants to show that the human body is almost converted into an animal. Jansas' video works have a social dimension, which the artist sees as the social bottom, where each of the functions starts to be an "animal" body "without a soul".

The performance titled The multiplicity anthology presents Jansas with a rope tied to one leg, running out and falling apart, without suffering real pain. In the performance In My Own Juice (1998), the artist draws blood from his own arm and transfers it to himself by sticking the needle in his butt. Blood transfusion into his own body is associated with the body's transgression. A film/video performance The Way Home, created in 2000, documents the artist on a night out drinking at the pub, and the journey home in his inebriated state. The point of view of the camera is from the artist's body, and so the film provides the viewer with the experience of a chaotic night of revelry. In Short Anthology of Meaningfulness (2003) the artist, with his foot tied to the floor, continually tries to run away, his body snapped back by the rope when he reaches its end. Upon all this artist's experience with his own body, we find ourselves raising the following questions: on which level is the body a private matter? "How far is it possible to go in destroying one's own body and health? Where is the border which is not possible to overstep?"18. His own social experience was provocative and influential for his creativity. In one of his interviews he stated that "in general, my performances for the most part came from all kinds of life situations". He rejects the border between life and art and points out that "art is »über alles« (about everything); same I think and today".

${ }^{17}$ Performing the East: Performance Art in Russia, Latvia and Poland since 1980, IB Tauris, 2013, http://performingtheeast.com/evaldas-jansas/ [accessed: 1.03.2017].

${ }^{18} \mathrm{~K}$. Šapok, Kad sveikas kūnas kadagiais kvepètų/That a healthy body smell good, "7 meno dienos" 2014, no. 9 (1070), http://www.7md.lt/daile/2014-03-07/kad-sveikas-kunas-kadagiais-kvepetu [accessed: 7.03.2014]. 
However, the importance nevertheless lies in the transgression, transformation of the body, which does not occur from one image, bodily concept or one kind of being to a qualitatively different. This is a return, regression of the body into body without "cultural prejudices". In other words, we have to deal with the situation in which the subject and the object merge into a whole and the bodily metabolism, in which the concept of the soul is reduced to bodily juices, snot, saliva, all the secretions that the artist is trying to bring back into himself (the performance In My Own Juice). But this is not a desperate attempt to retrieve some kind of identity. On the contrary, it is the social gesture of annihilation of any identity and an attempt at transferring the body to the sphere of instinctiveness, yet instinctiveness in a more nihilistic sense. In this metaphorism of Jansas' shocking anti-metaphorical performances it is possible to find the act of returning to the pre-human, pre-civilized state. The real and symbolic essence and meaning of this act are understandable and work only in the sociocultural context.

The radical animalism of Jansas' performances expresses not only the highest point of asociality, but also the highest point of vitality, which is liberated from social repressiveness. Finally, this is "a romantic grain" of cynicism of the Jansas' performance concept.

Jansas' motto "art »über alles «" (about everything) has a philosophical explanation and is close to Julia Kristeva's definition of "abject". She points out that "on close inspection, all literature is probably a version of the apocalypse that seems to me rooted, no matter what its socio-historical conditions might be, on the fragile border"19. Kristeva says that the "abject refers to the human reaction (horror, vomit) to a threatened breakdown in meaning caused by the loss of the distinction between subject and object or between self and other", and it is important for understanding both biological and social senses of Jansas' performances. To him, body as materiality in all kinds of its manifestations is the matter of artistic reflection. The visuality of Jansas' performances and pieces of manifest tell us that he struggles against "shame of compromise".

${ }^{19}$ J. Kristeva, Powers of Horror: An Essay on Abjection, transl. by L. S. Roudiez, Columbia University Press, New York 1982, p. 207. 


\section{Svajone and Paulius Stanikas: the World in Ruin}

The works of Svajone and Paulius Stanikas are characterized by the confrontation of the different layers of meaning, expressed through opposition of form and content or simply juxtaposition of differing objects, dominant iconography of the body/bodily reality, and distinctive (pseudo) retro-aesthetic approach.

In the early period, Svajone and Paulius Stanikas sharply deconstructed the concept of the human body through a pronounced visual self-destruction (reconstructions, simulations of criminal, fatal situations). It was a stage, at which the social, cultural, etc. images of the body became contaminated, disfigured and raped. The artists find a space, in which life and death, soul and body, eroticism and necrophilous pornography suddenly lose their conventional and conceptual differences, and the body becomes a paradoxical mixture of all this characters: some kind of monster, Frankenstein or "walking dead". This is an extremely shocking corporality, stepping over the line of itself. It should be recalled that in the early 1990s all of Lithuania's reality functioned in a regime of radical corporality or sensation as in reality, as in the media. Moreover, at this time the reality surpassed any sensation and transgression in the mass media and shocked to a much larger extent than today.

In their later works, Stanikas moved away from the radical deconstruction of the body, and concentrated on the image of the body as an object of commercial and ideological mediation. In this context, the body becomes more and more material in the works of artists, but not in the sense of turning into animal corporality as in Evaldas Jansas' performances, and not in the sense of a man-cyborg, but by erasing the line between the body and the consumed matter. The body in the modern creative concept of Stanikas' is deeper, composes and fits into the material structures of the current civilization and culture. This body as a matter in the system of matters (Baudrillard) obtains a status, which is not higher or lower than any other matter. This body is consuming and consumed (in some ways similar to the Renaissance concept "all devours all"), classifying and classified, recyclable, as well as other matters. It is the process of reanimation of matters and dematerialization of the body (and soul), which crosses out the line between "thing" and "body".

With their large-format photographs, huge drawings in leaden shades of grey, terracotta sculptures and video, the Stanikas are quite disconcerting. They 
use each medium for its own specific qualities (Christian Caujolle). The unique and extreme character of S. and P. Stanikas works is reached by choosing the highest and the lowest. The top and the bottom are together (Monika Krikštopaityte்). The willingness to change the understanding of the woman's role (feminism), to protect the weak (social criticism) or to grieve for victims (Holocaust theme) could be found in separated works by S. and P. Stanikas (Monika Krikštopaityte). They expressed a radical questioning of human nature through enacted deaths, sexuality, morbid, violence, aggression directed towards others and themselves, as well as exhibitionism.

In the article "Eastern Europe's Tales of Terror: the Art of the Stanikas", Tomek Kitlinski and Pawel Leszkowicz declare that to them there "is no significant other, only the oneness of life, creativity, and art". It is possible to suggest a relationship based on sadomasochism not only towards each other but also towards the viewer. Performing pain for the camera and for yourself and inflicting pain on the viewer is a method of exploring the personal psyche. The erotic dimension of the Stanikas is close to pornography. Only the convulsive beauty and perverse strangeness transport these works into a different register of visual imagination. Stanikas' portraits and self-portraits create idols of perversion, religion, and totalitarianism.

The sadness of the humans' faces or figures mixes with the grotesque of bodies. On the one hand, the images of the death bed, on the other, convulsive nakedness prevailed. The Stanikas convey the trauma. Invasions, crossing frontiers, attacks in the geopolitics of Eastern Europe correspond to the breach of the borders of the body. The breach of the body politic and the breach of the human body. The art of the Stanikas is a dream vision of the past and present horrors of Eastern Europe.

In the photographs of the Stanikas there is a number of dismembered and wounded bodies exposed for voyeuristic pleasures to counter the oblivion of pain. The artists' purpose is to attack the viewer, in spite of the protection of the glossy photographic surface, and bring the difficult memories and experiences back. The Stanikas provide visual pleasure and emotional terror through the lurid sexual allure of deformed and weird bodies and body parts. A sculpture of three pairs 
of cut Hands for Prayer, Alms and Fighting forms a poignant social commentary on human fragility and evil ${ }^{20}$.

The bodies of the ancestors and of hostages were burned on pyres. The Stanikas' Fire Poems are grisly photographs of convulsed, charred bodies - transformed by the pain of fire. Photography here is naked, screaming, and mysterious, yet artificially staged and fictional. In Fire Poems the images of swastika, ruined palace, and luxurious candelabras evoke emptiness and the cruelty of history inscribed in the architecture and its decoration. The spaces are ravished by the destruction and opulence of 'fascinating fascism' (Susan Sontag) of the past and of the present. If the Stanikas look back into the past of Eastern Europe, they do not have illusions. Their vision is dark: in this part of Europe the vampire and psychoanalysis was born - and the horror of totalitarianisms was real.

How to represent the horror of the Eastern European past and present? Is the art of the Stanikas, their infusion of the photographic surface of today with old traumas and bodily extremities, one of the (im)possible ways? The dark photograph from the series World War shows the corporate logo of Mercedes crowning a prison-like gothic castle. As we mention, the representation of abject is not a narrative - according to Julia Kristeva - but a vision: it is not an aletheia, but an apocalypse. The abjection in Eastern Europe founded an iconography - the delirium of predictable sex and violence in the critical art of Stanikas.

\section{Conclusions}

Reconceptualization of body from the philosophical point of view undergoes such postmodern definitions as the "thinking body" or the "virtual body" or "body without organ”. The concept of 'deterritorialization' signifies a political reframing of the body which Deleuze and Guattari described as "a not closed entity, but as an open and dynamic system of exchange, constantly producing modes of subjection and resistance and becomings" 21 . Art and art philosophy critics experience "the need for a systematic meta-discursive approach" which would explain innovative art tendencies on the interdisciplinary level. New materialists explain how

\footnotetext{
${ }^{20}$ K. Sapoka, S\&P Stanikas: Chastity Belt, [in:] Moscow Biennale of Contemporary Art, Catalogue de l'exposition 2011.

${ }^{21}$ A. Lepecki, Exhausting Dance, Routledge, New York 2006, p. 5.
} 
matter (body in our case) comes to matter and how (public) discourses come to matter (body). New materialist scholars use matter (body in our case) as their focal point. Zooming in on the matter of art, they move away from a framework of representation and start to be in fact part of the phenomena that they study.

Reconceptualization of body includes such notions as abjection, anti-consumerism, commodities, existential border situation, post-humanism, rejection of sexually attractive corporality, convulsive beauty and perverse strangeness, body's transgression, deromanticizing, demetaphorization, and desocialization of body. All of these concepts were mostly adapted by creative and artistic researchers that have a tradition of thinking radically, "outside the box", in order to make sense of the world.

\section{Bibliography}

Appadurai A., Introduction: Commodities and the Politics of Value, [in:] The Social Life of Things: Commodities in Cultural Perspective, ed. by A. Appadurai, Cambridge University Press Cambridge 1986, p. 3-63.

Bartky S. L., Foucault, femininity and the modernization of patriarchal power, [in:] Feminism and Foucault: Reflections on Resistance, ed. by I. Diamond \& L. Quinby, Northeastern University Press, Boston 1988.

Braidotti R., A Critical Cartography of Feminist Post-postmodernism, "Australian Feminist Studies" 2005, vol. 20, no. 47 (July).

Bullington J., The Expression of the Psychosomatic Body from a Phenomenological Perspective, Springer, New York-London 2013.

Douglas M., Purity and Danger: An Analysis of the Concepts of Pollution and Taboo, Routledge and Kegan Paul, London 1966.

Graw I., High Price: Art Between the Market and Celebrity Culture, Sternberg Press, Berlin 2009.

Halberstam J. M. and Livingston I., Posthuman Bodies, Indiana University Press, Bloomington 1995.

Johnson M., The Meaning of the Body. Aesthetics of Human Understanding, University of Chicago Press, Chicago 2007.

Jones A., Body Art: Performing the Subject, University of Minnesota Press, Minneapolis 1998.

Kitliński T., Dream? Democracy! A Philosophy of Horror, Hope \& Hospitality in Art \& Action, Maria Curie-Sklodowska Press, Lublin 2014.

Kristeva J., Powers of Horror: An Essay on Abjection, transl. by L. S. Roudiez, Columbia University Press, New York 1982.

Krikštopaityte M., Fantazijos apie siaubą/Fantasies About Horror. "Lithuanian Photogra- 
phy, Yesterday and Today '06" 2006, Vilnius, http://www.photography.lt/lt.php/Metrastis?met=19\&page=97 [accessed: 1.03 .2017 ].

Krikštopaitytė M, Pasyviai agresyvus, http://www.7md.lt/autorius/152 [accessed: 1.03.2017].

Lepecki A., Exhausting Dance, Routledge, New York 2006.

Merleau-Ponty M., Phenomenology of Perception, transl. by C. Smith, Routledge, London 1962.

Performing the East: Performance Art in Russia, Latvia and Poland since 1980, IB Tauris, 2013, http://performingtheeast.com/evaldas-jansas/ [accessed: 1.03.2017].

Sapoka K., S\&P Stanikas: Chastity Belt, "Moscow Biennale of Contemporary Art, Catalogue de l'exposition" 2011.

Šapoka K., Kad sveikas kūnas kadagiais kvepètu/That a healthy body smell good, "7 meno dienos" 2014, no. 9 (1070), http://www.7md.lt/daile/2014-03-07/kad-sveikas-kunaskadagiais-kvepetu [accessed: 7.03.2014].

Thomas N., Entangled Objects: Exchange, Material Culture, and Colonialism in the Pacific, Harvard University Press, Cambridge 1991.

Zukauskaite A., Imaginary Identities in Contemporary Lithuanian Art, “Art \& Research: A Journal of Ideas, Contexts, and Methods" 2008, vol. 2, no. 1, p. 7-9.

\section{Zusammenfassung}

\section{Der Körper als neues soziales Medium in der litauischen Performatik: Wie der Diskurs in die Materie eingeht?}

Der Artikel beschäftigt sich mit dem Begriff des neuen Materialismus und erforscht die Frage, wie der neue Materialismus visuelle Künste auf eine innovative Art wahrnimmt: durch die Verbindung von künstlerischer Praxis, der Kunst als Forschung und der philosophischen Analyse. Ausgewählte künstlerische Arbeiten von S \& P Stanikas und Evaldas Jansas werden unter Anwendung der Methoden des neuen Materialismus als Rekonzeptualisierung des Körpers in der litauischen Kunst interpretiert. Untersucht wird der geopolitische und antiideologische Hintergrund, vor dem die visuellen Künstler in Litauen und Polen von 1960er bis zu 1990er Jahren gegen kulturelle Dichotomien kämpften: männliche und weibliche Körper, traditionelle oder gegenwärtige Kunst, Künstler als freies Individuum oder an Ideologie gebunden. Unter Verwendung des Terminus "affirmativ" von Rosi Braidotti wird im Artikel die Frage gestellt, ob man anhand der analysierten Fälle argumentieren kann, dass "affirmative Politik auf der Suche nach alternativen Visionen und Projekten Kritik mit Kreativität verbindet".

Schlüsselworte: abject, Ware, Rekonzeptualisierung des Körpers, emotionaler Terror, Materie, neuer Materialismus, Posthumanismus, Sexualität, Gewalt 


\section{Streszczenie}

\section{Ciało jako nowe medium społeczne w performatyce litewskiej: jak dyskurs wchodzi w materię?}

Artykuł zajmuje się pojęciem nowego materializmu i bada kwestie, jak nowy materializm dostrzega sztuki wizualne w sposób nowatorski - poprzez skrzyżowanie praktyki artystycznej, sztuki-jako-badań i analizy filozoficznej. Wybrane prace artystyczne autorstwa S \& P Stanikas i Evaldasa Jansasa zostają zinterpretowane w referacie jako rekonceptualizacja ciała w sztuce litewskiej, posługując się metodami nowego materializmu. Eksplorujemy tło geopolityczne, antyideologiczne, w którym artyści wizualni litewscy i polscy zmagają się z binaryzmami kulturowymi od lat 1960. do 1990: męskie-kobiece ciała, sztuka tradycyjna czy współczesna, artysta jako wolna jednostka czy przywiązana do ideologii. Posługując się terminem Rosi Braidotti „afirmatywny”, w artykule stawia się pytanie, czy można argumentować na podstawie analizowanych przypadków, że „afirmatywna polityka łączy krytykę z kreatywnością w poszukiwaniu alternatywnych wizji i projektów”.

Słowa kluczowe: abject, towar, rekonceptualizacja ciała, terror emocjonalny, materia, nowy materializm, posthumanizm, seksualność, przemoc

Information about Authors:

BASIA NIKIFOROVA, Lithuanian Culture Research Institute, Lithuania; adres do korespondencji: Lithuanian Culture Research Institute, Vilnius, Saltoniškių g. 58, LT-08105; e-mail: bnikiforova@hotmail.com;

KESTUTIS SAPOKA, Lithuanian Culture Research Institute, adres do korespondencji: Lithuanian Culture Research Institute, Vilnius, Saltoniškių g. 58, LT-08105; e-mail: kestas.sapoka@gmail.com

\section{(c) BY-NC-ND}

